\title{
Conceptualizing Basic Psychological Needs (BSPN) and Motivation Regulations as Antecedents for Guided Teachers' Work Commitment And Satisfaction
}

Norlida Idrus, Nor Aniza Ahmad, Noor Syamilah Zakaria

To Link this Article: http://dx.doi.org/10.6007/IJARBSS/v10-i11/8145

DOI:10.6007/IJARBSS/v10-i11/8145

Received: 05 September 2020, Revised: 15 October 2020, Accepted: 04 November 2020

Published Online: 28 November 2020

In-Text Citation: (Idrus et al., 2020)

To Cite this Article: Idrus, N., Ahmad, N. A., \& Zakaria, N. S. (2020). Conceptualizing Basic Psychological Needs (BSPN) and Motivation Regulations as Antecedents for Guided Teachers' Work Commitment And Satisfaction. International Journal of Academic Research in Business and Social Sciences, 10(11), 779-803.

Copyright: (c) 2020 The Author(s)

Published by Human Resource Management Academic Research Society (www.hrmars.com)

This article is published under the Creative Commons Attribution (CC BY 4.0) license. Anyone may reproduce, distribute, translate and create derivative works of this article (for both commercial and non-commercial purposes), subject to full attribution to the original publication and authors. The full terms of this license may be seen

at: http://creativecommons.org/licences/by/4.0/legalcode

Vol. 10, No. 11, 2020, Pg. 779 - 803

Full Terms \& Conditions of access and use can be found at http://hrmars.com/index.php/pages/detail/publication-ethics 


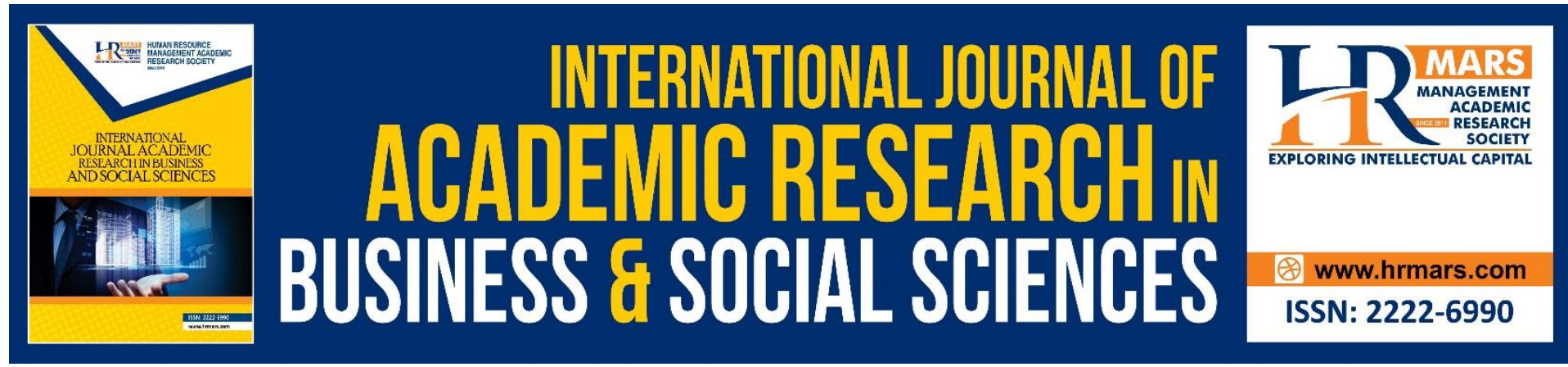

\title{
Conceptualizing Basic Psychological Needs (BSPN) and Motivation Regulations as Antecedents for Guided Teachers' Work Commitment And Satisfaction
}

\author{
Norlida Idrus, Nor Aniza Ahmad, Noor Syamilah Zakaria \\ Faculty of Educational Studies, Universiti Putra Malaysia, Malaysia \\ Email: norlidaidrus@gmail.com,nor_aniza@upm.edu.my, syamilah@upm.edu.my
}

\begin{abstract}
Guided teachers in Malaysia is carefully selected by the school, district education agency and the state education department. The selection is based on their low teaching competency. The guided teachers or known as GDB will be guided through mentoring by the School Improvement Specialist Coach (SISC+). It is found that amongst the important element that determine teachers' competency are work commitment and satisfaction. Although the guided teachers programme has been conducted for 6 years (2014-2020), but the current literatures only focusing on the mentoring and the teachers' perception on the SISC+. There is still limited study that focusing on the GDB work commitment and satisfaction after receiving mentoring from the SISC+ even though those two elements are imperatives to be studied. Henceforth, the aim of this article is to provide arguments on potential solutions to tackle on the said problem. It is argued that motivational capacity is paramount in enhancing work commitment and satisfaction. This study embarks to describe and conceptualize the important of Self-Determination Theory (SDT) in affecting both the work commitment and satisfaction of the guided teachers. It includes the discussion on Basic Psychological Needs (BSPN) and Motivational Spectrum. Initially, the article will discuss on the guided teachers work commitment and satisfaction and follows by the discussion and conceptualization of SDT. The effect of SDT including BSPN and motivational spectrum on commitment and satisfaction will be discussed next. The article shall contribute to the discussion and deliberation on teachers' motivation, work commitment and satisfaction
\end{abstract}

Keyword: Guided Teachers, Motivation, Self-Determination Theory, Work Commitment, Education, Malaysia

\section{Introduction}

Teachers and teaching profession are always in the centre of community attention. This is mostly contributed to the fact that teachers are directly impacted by any policy changes or new direction constructed by the government. Teachers are also viewed as a medium to implement any macro decision made in regards to education at the federal level. Scholars in education have been indicated that practices conducted by the teachers in the classroom 
significantly determined their teaching quality (Bassi, Meghir, \& Reynoso, 2019; Glasser, 1986). In the context of Malaysian education landscape, the teaching quality envisioned by the ministry of education in Malaysia Education Blueprint (2013-2015) can only be achieved if all the teachers throughout the country are able to carry high competency in teaching (Kementerian Pendidikan Malaysia, 2013b). Competency in teaching is directly associated with the teacher's individual capacity and capability in the classroom. It comprises of their personal, professional and social skills such as personality, comprehension in pedagogical structure of teaching, subject-matter expert and integration with the surrounding community (Hatlevik, 2017; Siraj \& Ibrahim, 2012). Teaching competency is also define as the capability of teaching effectively in the classroom (De Ketele, 1996; Hollins, 2015). Empirical studies have shown that teacher's teaching competency in the classroom as one of the essential factors in determining student success rate (Darling-Hammond, 2000; Haycock, 1998; Wahyuddin, 2017).

In a society that value education as an imperative antecedent of socio-economic development, the students' success is one of the crucial contributing factors. Therefore, it is not surprising that every year the Malaysian Ministry of Education (MOE) continuously underline efforts and plans in order to improve the teaching capacity amongst Malaysian teachers. This can be identified in the MOE efforts to establish School Improvement Specialist Coach (SISC +) in 2014 to assist the teacher to improve students' academic performance particularly in Band 4-6 within MOE classification (Kementerian Pendidikan Malaysia, 2013a). The SISC + is responsible for guiding low-skilled teachers in the teaching and learning process in the classroom. As of 2018, a total of 28,000 guided teachers (GDBs) are placed under SISC + throughout Malaysia (Kementerian Pendidikan Malaysia, 2018) This initiative by SISC + is seen to enhance teachers' ability to implement teaching and learning in the classroom (Izab, 2015). Coordination and operation of SISC+ programme begin with the government approached senior teachers with excellent teaching performance and experience as the coaches. There are several different coaches in each district in each state in Malaysia. There will be different coaches for different subjects' fields for both primary and secondary schools. These shall ensure the quality of these coaches. The selection of low competency teachers as participants of these programme were made by the school administration. There will be extra attention given on low-achieving school which were based on their performance in the annual public examination.

However, after four years (2014-2018) of the implementation of mentoring and mentorship of the GDB, findings in the empirical studies had only focus on the impact of mentoring and guiding on the quality of teaching. Lack of attention is given on the impact of these mentoring and guiding on teachers' work commitment satisfaction. For instance, a study conducted by the Radhiah Said, Brahim, \& Md Sabil, (2016) which examines the impact of mentoring and guiding by SISC+ on Malay Language GDB teachers' teaching competency in Samarahan, Sarawak. The study found that this program is quintessential and relevant to help teachers implement high-quality teaching and learning. In addition, a study conducted by Leng, (2015) looking at GDB teachers in mathematics by using Appreciative Inquiry (AI) theory found that GDB planning and practice had no difference before and after guidance and mentoring by SISC +. Thus, it shows that there is still huge room for study in association with understanding the GDB work commitment and satisfaction. There is still limited research that focuses on aspects of GDB work commitment and satisfaction after receiving guidance from SISC + despite the vitality of this aspect. Moreover, it is argued that commitment and satisfaction 
aspects contribute to teachers' achievement, absence, burnout and turnover (Kosnik, Beck, \& Lin Goodwin, 2016; Reyes, 1992).

Hence, to overcome the limitation, this study aims to investigate on the antecedent aspect of the guided the teachers. Namely, this study tries to answer two important question. First, does motivation has the capability to affect guided teachers' work commitment and satisfaction. Second, what are the factors that could influence the teachers' motivation. Answering these two questions enable a comprehensive understanding on this programme. Furthermore, it contributes in enhancing literatures within the realm of guided teachers in field of education.

To answer these two questions, this study will be using Self-Determination Theory (SDT) as the underpinning theory. The study will first conceptualize Basic Psychological Need (BSPN) to be the underlying foundation that has influence on the teachers' motivation. Furthermore, this study will scrutinize the concept of motivation into several element based on the explanatory capacity of SDT. Thus, discussing the elements capacity to influence the teachers' commitment and satisfaction. Henceforth, this article structure is as follows: First, the article will introduce SDT and discuss elements within BSPN. It will then continue by discussing motivation elements and concept of work commitment and work satisfaction within teaching realms. Next, it will show how BSPN elements are able to influence motivation and how motivation elements would be able to influence the teachers' commitment and satisfaction. Theoretical and conceptual framework towards the end of this article. It will discuss the concluding remarks and way forward in the final section of this article.

\section{Self Determination Theory}

Self Determination Theory (SDT) is a theory that evaluate individual trustfulness towards its environment. The theory itself focus on the nature of motivation which is "Why the behaviour occurs?" (Tremblay, Blanchard, Taylor, Pelletier, \& Villeneuve, 2009). Foundation of this assumption is that human is an active, mentally expanding, and has a natural tendency to "integrate physical (action) with the sensory and integrate themselves within the larger social structure" (Ryan \& Deci, 2000, p. 229). Besides, it is also a study on human inner-tendency and natural psychological needs which both turn to be foundational for integrating personal motivation with personality. The study also looks on the properties that enhance the positive process (Ryan \& Deci, 2000). Based on the past empirical studies, there are three essential properties know as basic psychological needs (BSPN). There are autonomy, competency and relatedness (Deci \& Ryan, 2002). These three are the foundation to optimally enhance individual functionality, contribute to growth tendency, integration of social constructive development, and individual well-being.

There are several studies employed SDT technique to evaluate the effect of environment on obstructing and weakening self-motivation, social function and individual well-being. Nevertheless, SDT is not only meant to investigate only on positive development but also it tested social environment which might has contradiction value on the positive tendency. Besides, SDT main focus is to provide a different approach on motivation which is by identifying different motivation constructs with each of them will have specific effect on individual performance, learning capability, experience, and well-being. SDT also aim to explain construction and maintenance of those motivation constructs as well as the factors that inhibit and hinder individual motivation.

The SDT approach was extensively utilized to guide researchers in education discipline (citation). There are two important aspects within SDT which are basic psychological need 
(BSPN) and motivation element. According to SDT, fulfil BSPN will enhance individual motivation level. Hence, the next sections will discuss both BSPN and motivation element according to SDT.

\section{Basic Psychological Need}

SDT comprise of an assumption that there is a foundation on the mechanic of motivation that energize and dictate human behaviour (Deci \& Ryan, 2010). The foundation is know as basic psychological need (BSPN). According to the theory, "need" refers to basic necessities that is requires for human development and integrity (Ryan, Sheldon, Kasser, \& Deci, 1996). Moreover, basic psychological need is an 'essential nutrient' for individual which allow them to function at optimum level. The analogy of a plant could represent the situation. Plant require water, sunlight and mineral for it to growth and bloom (Ryan \& Deci, 2000). Past empirical studies have shown how BSPN influenced work happiness through controlling and reducing anger, anxiety and lost of tempers (Collie, Shapka, Perry, \& Martin, 2016; Fernet, Austin, Trépanier, \& Dussault, 2013). By increasing or experiencing work happiness, this shall create another foundation for effective teaching and learning in the classroom (Holzberger, Philipp, \& Kunter, 2014). Within SDT, there are three elements of basic psychology that have been identified. There are need towards autonomy, competency and relatedness (Deci \& Ryan, 2010).

\section{Autonomy}

The concept of autonomy in general is self-reliance, independence and self-management (Deci \& Ryan, 2010) However, through the SDT approach, autonomy is defined as the autonomous behaviour of the congruent through the process of knowing oneself and making the choice and deciding on one's own behaviour (Ryan \& Deci, 2000). The concept of autonomy is contrary to controlled behaviour. In teaching, the concept of autonomy support is often misunderstood with the concept of laissez-faire and structural freedom. Autonomy does not grant full liberty but maintain structural support especially on control over adverse actions in order to equip student or faculty with autonomy (Jang, Reeve, \& Deci, 2010). The need for autonomy also represents the desire of the individual to feel free and to have the freedom on the psychological aspects of the activity (De Charms, 2013; Deci, Olafsen, \& Ryan, 2017). Despite there are claim that associate concept of autonomy from the SDT perspective with the concept of autonomy from an organizational psychological perspective, there are clear distinctions between the two constructs (Morgeson \& Humphrey, 2006).

Autonomy from an organizational psychology perspective focuses on the process of latitude decision making and control over the use of skills by an organization (Karasek, 1979). It deals with the questions such as, "Does an employee have the autonomy to do work outside the job description?". The concept is further explained by Hackman and Oldham, (1976) Hackman and Oldham (1976) in which they assert that autonomy is the real freedom for an employee in an organization to form a work schedule and to determine the procedure for performing it. On the other hand, autonomy from the concept of SDT primarily refers to the subjective experience gained from psychological freedom and choice while carrying out (Gagné, Chemolli, Forest, \& Koestner, 2008). This means that autonomy focuses on the characters or meaning in a single task. Autonomy in the context of GDB is essential as it shows that the guided teachers are being both supported and guided as they implement their teaching techniques in the school. This also means that the teachers are not asked to do just what the school wants but are given options to implement according to their own way. 
In addition, autonomy plays an important role for GDB when they have to handle issues or problems as each individual has a different response situation, issue or problem that they have to face. Furthermore, teaching require a higher degree of autonomy in comparison to other vocations as teaching techniques needs to be constantly modified and adapted to meet the needs of different students which were mostly comprise of different attitude and capability (Collie et al., 2016). In addition, teachers face a great amount of pressure, which will affect their well-being, motivation, job satisfaction and different work commitments. (Kyriacou, 2011).

\section{Competency}

In addition to autonomy, basic psychological needs according to SDTs refer to an individual's need for competency. Competency can be refers to the desire to feel effective when it comes to the environment (White, 1959; Ryan \& Deci, 2000). It refer to individual tendency to stand out and at the same time try to explore and exploit the environment. It will allow them to gauge their capacity while engaging in challenging tasks and developing one's skills (Broeck, Vansteenkiste, \& Witte, 2010). Satisfying one competency provides an opportunity for individuals to adapt to a complex and changing environment, while frustrating competency is related to one inability and lack of motivation (Ryan \& Deci, 2000).

It is almost identical to the constructs in Theory of Value Expectation (Vroom, 1964) and Theory of Self-Effectiveness (Bandura, 1978), but there are some differences between the three of them. Specifically, in accordance with Self-efficacy Theory and Expectation Theory, outputs from self-expectation and self-efficacy indicate that awareness of one's ability to achieve a specific task in the future is realized. These will turn to be positive value as they try to achieve their goals.

This contrasts with the SDT perspective which refers to the sense of satisfaction that comes from individual ability to perform a task (Broeck, Vansteenkiste, De Witte, Soenens, \& Lens, 2010). Despite these differences, there is anecdotal evidence that shows a correlation between the concept of extension from the perspective of Self-efficacy Theory and SDT (Broeck et al., 2010). This correlation indicates that the concept of competence described by the SDT can be applied to the assessment of GDB's basic psychological level. The GDB will find themselves able to compete and provide the best services when they are able to perform their responsibilities well and complete challenging tasks. This shows that the concept of competence is fundamental to the basic needs of a teacher (Broeck et al., 2010).

\section{Relatedness}

The last component of the Basic Psychology Needs is relatedness. Connectivity is a psychological concept related to human social relation, which is an individual need for a sense of belonging (Baumeister \& Leary, 1995). It enables individuals to interact in a friendly and pleasant environment and to feel a sense of belonging and connectedness with the others (Skinner \& Edge, 2002). Humans need to connect and interact with others so that they can feel connected and maintained (Baumeister \& Leary, 1995). This will make them feel confident that they will receive assistance from other members of the community in the social structure when they faced any hindrance or problems.

Besides, it will solidify their personal comfort. An individual personal comfort is essential as it prevents them from amplifying the problem they are facing (Berscheid \& Reis, 1998). The happiness and well-being of a person depends on their interpersonal relationships (relatedness). This sense of well-being has an impact on emotional treatment and behavioural 
disorder (Baumeister \& Leary, 1995). If we look at the application of this concept on GDB, this relatedness will make GDB more concerned and at the same time desire to be concerned by the other members (e.g. colleagues, administrators and students) of a school. These needs are satisfied when they feel connected to other people in their workspace.

In conclusion, the basic psychological needs which comprise of autonomy, competence and relatedness are the key elements in determining the psychological function of GDB. However, SDT considers these basic psychological needs to not only has a capacity to influence an individual's behaviour but the mechanism of function is based on motivational element within them. Motivation in SDT is an essential element that stimulates the strengthening process of individual psychology. Therefore, in the next section, the discussion will continue on the motivational elements described in SDT and to what extent they are related to the commitment and job satisfaction of the guided teachers.

\section{Motivation Elements}

The key point in SDT is that it distinguishes amotivation with motivational states. Amotivation is an act without cause and purposes while motivation is an act involving purpose and cause. When an individual is in an amotivation state, the individual will either not act at all or act without his or her own reasons. The action is only made in order to follow the rules or orders. There are multiple factors that lead to amotivation. For instance, amotivation is the consequence of not evaluating an activity (Ryan, 1995), not feeling competent to do it (Bandura, 1991), or not expecting any response and results from the activity (Seligman, 1975). The separation of the amotivation element and the concept of motivation is important as it enables these two situations to be evaluated in different ways. It also helps to explain concept of motivation in details.

Through the concept of motivation, SDT distinguishes between autonomous motivation and control motivation (Deci, \& Ryan, 1985; Howard, Gagné, Morin, \& Van den Broeck, 2016). These autonomous motivations include intrinsic motivation and internalized extrinsic motivation (in reference to motivational rules). Individuals who possessed autonomous motivation are motivated through his or her interest in an activity or because of the value and regulation of the activity has been integrated within them. Whereas, control motivation reflects the level of stress or persuasion the individual receives by external contingency or internal coordination such as involving the ego and guilt within the self.

Recent studies have shown that the more autonomous a person is, the more likely he or she is to enjoy life. Most of these empirical studies have combined different types of motivation into one index (referring to autonomy) or divided them into two categories, autonomous motivation (combination of intrinsic motivation and identified regulation) and control motivation (combination of intro-ejected regulation and external regulation) (Fernet, Stepanie, \& Vallerand, 2012; Langan et al., 2016; O'Neil \& Hodge, 2019; Vansteenkiste, Lens, $\&$ Deci, 2006). These studies highlight the importance of autonomous motivation and control motivation in learning, sports coaching and organization. However, there is still limitation on the findings especially in showing the capability of these different types of motivation on affecting individual well-being. This is important because for instance intrinsic motivation and identified regulation are usually classified as autonomous motivations that have different effects on one's well-being and performance.

As explained earlier, SDT Theory further elaborates on the concepts of autonomous motivation and control motivation when it is divided into several different types of motivation. It includes intrinsic motivation as well as some other sub-components of extrinsic 
motivation (Deci \& Ryan, 1985, 2000). Intrinsic motivation refers to an action because of his or her decided to do it. When an individual is intrinsically motivated, that means the individual is fully integrated. The individual will be able to exercise self-control, perform activities based on his or her interests, and be psychologically functioning on his own without the need for help in the form of rewards or external constraints (Deci \& Ryan, 1985). This intrinsic motivation construct explains the self tendency for assimilation, domination, spontaneous or natural interest and exploration that is fundamental to individual cognitive and social development. It can be known as a major source of pleasure and passion in one life (Csikszentmihalyi, \& Rathunde, 1992; Ryan, 1995).

Although intrinsic motivation is an important element in SDT, it is not the only type of motivation in the theory. Furthermore, not everyone is motivated intrinsically, especially when they went through their childhood with high motivation and intrinsic motivation but are blocked or reduced by social pressure to do things that are not of interest and need to fulfil various responsibilities (Deci \& Ryan, 2010). Thus, the next question raised is "How individuals who are not intrinsically motivated decided to do something and what motivate them to do it, and how this motivation affects their quality of behavior, sustainability and wellbeing?". In order to overcome this limitation in theoretical explanation, SDT underlines several other motivation elements that is associated with extrinsic motivation.

Extrinsic motivation is an act of doing an activity or thing in order to gain results or benefits. It is opposite from the intrinsic motivation which emphasize individual action's objective for individual self-satisfaction. According to the SDT approach, these motivational differences reflect the level of distinction as well as the value of the internalized and integrated behavioural regulation of behaviour (Ryan \& Deci, 2000). Internalization refers to the individual adopting a value or regulation while integration refers to the process of transformation of the regulation or value through self-interpretation (Ryan \& Deci, 2000). Through the SDT theory, it can project the psychological processes that are involved in gaining and accepting new values or goals for an individual. The process of internalization also refers to the active assimilation of integrated behaviour that is inherently alien to an individual (Ryan, 1995). Internalization does not cause extrinsic motivated individuals to change to intrinsic motivation but rather a tendency towards autonomous processes of a motivational regulation.

Extrinsic motivation is broken down into four (4) sub-sections or elements within a continuum called motivational rules. This continuum as shown in Figure 1 shows that some rules are more likely to be motivated by the concept of autonomy while some other rules are more likely to be motivated by control. Intrinsic motivation and each of the motivation regulation in extrinsic motivation illustrate the different reasons for this behaviour and why it expresses different meaning to each level of motivation (Deci, Connell, \& Ryan, 1989). The SDT states that there are four types of extrinsic motivation that are regulated relatively by external factors or may be relatively autonomous to each of the rules based on their integration with the individual's values and goals. These types of motivations are arranged along the continuum indicating their level of internalization as shown in Figure 1. 


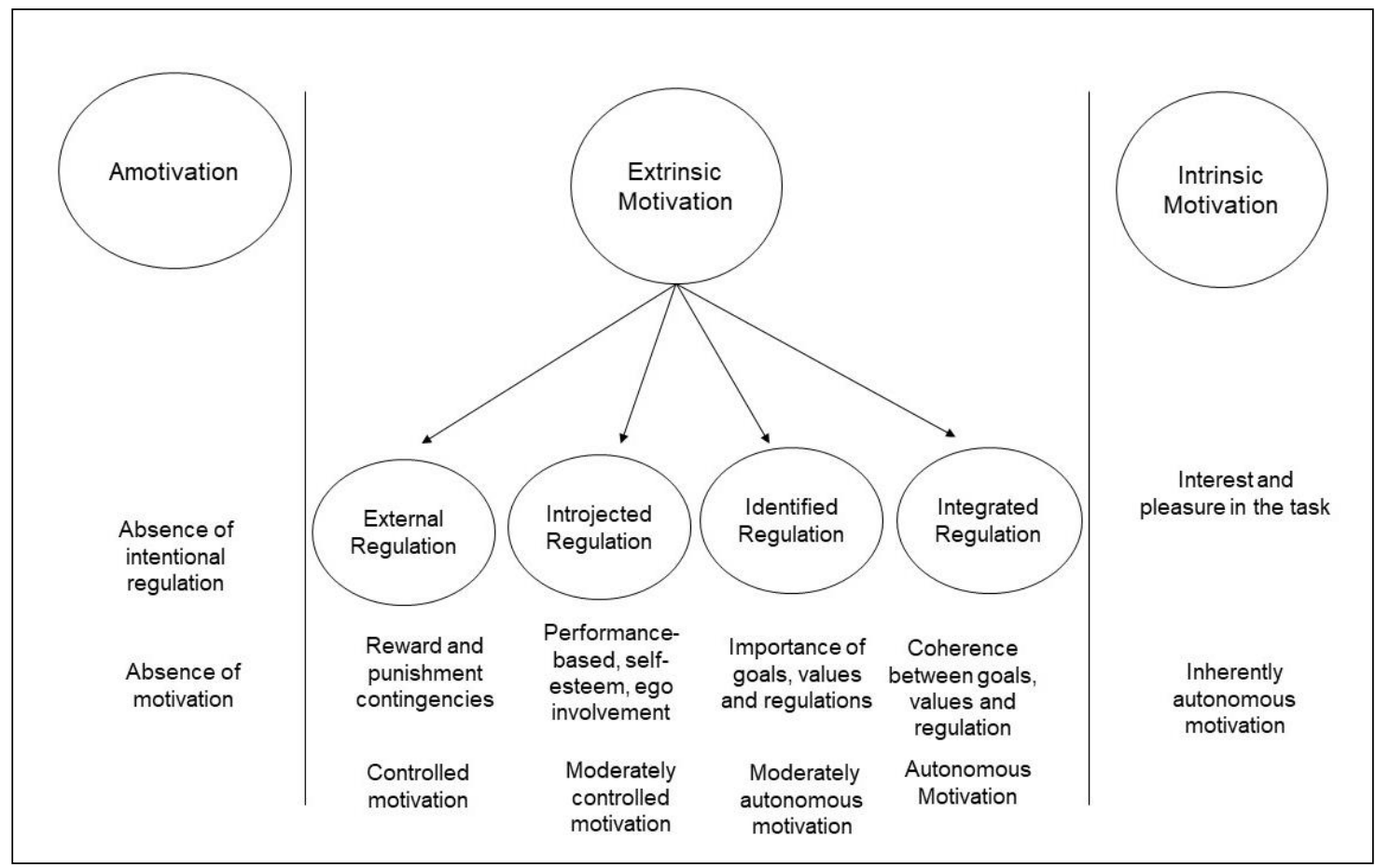

Figure 1: The Self Determination Continuum (Gagné \& Deci, 2005)

External regulation can be considered as the lowest level of motivation and its refers to act of engaging in activities for rewards or avoiding punishment. For example, a teacher performs a task directed by the school administrator for praise or because he or she does not want to be confronted by the school administrator. Then, the introjected regulation can be identified as motivation that propagate behaviour due to individual self-contradictions such as ego and guilt. For instance, a teacher is involved in a program at school not because the teacher wants to do it, but because he or she feels it is a must for "good" teacher to do it (self-guilt). According to Ryan \& Deci, (2000) this type of regulation is very desirable to be seen as a regulation within oneself, but at the same time it still consists an external value control over oneself.

Next, identified regulation refers to a person performing an activity based on their values and their own meaning which is a product of their own assessment. For example, teachers recognize the importance of learning new teaching techniques as it will be useful and valuable for them based on their benefits and skill improvement capacity. The last regulation is integrated regulation in which an individual identifies the value of an activity and then the value of that activity becomes part of that individual's value. For example, a GDB decided to become the school debate team's coach because of its deep interest in the activity. This twoway equilibrium between activity and self-worth value constitutes an integrated regulation as explained by SDT. The SDT further emphasize that these theories are still within extrinsic motivation, however, it has undergone the process of internalization. Therefore, it has the freedom to influence individual actions

In addition, identified regulation, integrated and intrinsic motivation is a prototype for selfdetermination motivation while amotivation, external regulation and intro-ejected regulation are categorized as non-self determination motivation. However, it is important to note that the SDT internalization model is not part of the Stage Theory. The Stage Theory briefly explains that every human behaviour will change according to its level. On the contrary, the 
SDT explains that these types of regulations converge into reference index to explain the extent to which individuals integrate the rules in their behaviour. Therefore, the SDT proposes that under any optimal circumstances, individuals may at any time integrate new or existing regulation that are partially internalized. In fact, a new behaviour may be internalized at any stage throughout the continuum depending on factors such as the organization context and the individual's experience (Ryan, 1995). Figure 2 shows the position of each element of motivation and the motivation regulation within the continuum of self-determination.

\section{Work Commitment}

Commitment is defined as a high association to an organization (Crosswell, 2006). Commitment is a person's attitude, which includes the intention, trust towards the behaviour on the job done (Cohen, 2003). Commitment is a sign for feelings reflection such as links, recognition and loyalty to an organization where it is the object of commitment (Geldenhuys, Łaba, \& Venter, 2014; Morrow, 1993). Commitment can also be seen as one dimension of effective organization through job performance and reduction in employee turnover (McDermott, Laschinger, \& Shamian, 1996; Miller, 2018). Moreover, according to Buchanan, (1974) commitment is defined as emotional commitment to achieving organizational objectives.

The argument is also supported by Marthis and Jackson, (2000) who stated that employee commitment will be reflected by their duration of stay in the organization and at the same time seriously participate in achieving the organization's goals. In addition, commitment is a clear benchmark for employee to show their empathy towards the organization's value and therefore work commitments can be used to measure employees' desire to stay in one organization or move to another organization (McNeese-Smith, 1996; Munyaka, Boshoff, Pietersen, \& Snelgar, 2017).

Studies in the field of education indicate that teacher commitment is similar as organizational commitment (Graham, 1996; Huber, 1999; Louis, 1998). However, the teaching profession is unique in that it is complex and rich with a combination of different types of vocations and not just the organization (school and education system). It also involves many stakeholders including parents, students, and colleagues. According to Reyes (1992); and Kosnik, Beck, \& Lin Goodwin, (2016), A committed teacher will be more diligent, punctual, not intentionally leaving school, willing to work outside formal school hour to achieve school's goals, overcome common problems, work to impact student achievement, trust and act to achieve school goals, strive for no personal interest and intend to remain in the school system. In addition, teachers' work commitments reflects their attitudes that influence their and behaviours they intend to perform (Cohen, 2003). This shows that as teachers become more committed to their tasks at school, they are more likely to act based on the skills and knowledge they acquired in order to achieve their goals (Demirbolat, Ihtiyaro, \& Karaba, 2017). Accepting the goals and values of a school is fundamental to the teacher's commitment to the school.

In general, there are many factors that influence GDB's commitment towards the school. Factors influencing this work commitment will cause GDB to remain committed to their work. These factors will affect their level of commitment not only in teaching but also in their role as a teacher. Based on previous studies conducted on teachers, in general, among the factors often associated with job commitment are job satisfaction, leadership style, and work environment (Mohamad, Kasim, Zakaria, \& Nasir, 2017; Saha, 2016), foundations of psychological needs (Collie et al., 2016), competence (Akram, Malik, Sarwar, Anwer, \& Ahmad, 2015) and emotional intelligence (Shafiq \& Akram Rana, 2016). All these factors will 
affect work commitment and in turn will affect the performance and achievement of the employee. As such, the GDB is no exception to the aforementioned factors. Furthermore, they will possess more stress as they are the centre of focus by SISC + and school administrators. Thus, based on the description discussed above, it is clear that work commitment is an important aspect in determining success of an organization or school's goals. In addition, this commitment can also be influenced by many other factors that ultimately determine the level of commitment of an employee or a teacher. Therefore, it is very important that the GDB is committed to the school in determining the success of the school's goals in helping to improve the student's achievement.

\section{Work Satisfaction}

Job satisfaction is defined as the individual attitude towards the job. The attitude is either a positive or negative feeling about their tasks and/or their work environment (Banerjee, Stearns, Moller, \& Mickelson, 2017; Bhuian \& Menguc, 2002; Dinham \& Scoot, 2000). Job satisfaction can also be defined on how employees of an organization feel about their job (Janssen, 2001). Similarly, these feelings can be positive or negative feelings, where more positive feelings translated into higher levels of employee satisfaction. In other words, the workers' positive emotion towards their place of work also explains their job satisfaction. Overall, job satisfaction is an individual's inner feelings that associate with his or her desire to succeed the job. Generally, it is also be known to be directly related to productivity of an individual's work. It also reflects the workers' joy, excitement and appreciation as a product of the effort put into their work. Job satisfaction is the key that leads to reward, income, and achievement for all goals and aspirations (Kaliski, 2007; Mittal \& Bhakar, 2018).

In addition, job satisfaction also involves emotional, cognitive and behavioural components (Bernstein \& Nash, 2006). The emotional components refer to a person's feelings about work such as boredom, anxiety or excitement. The cognitive component of a person's belief in his or her work, for example, the mental load and the challenges he or she faces. Meanwhile, the behavioural component of job satisfaction connected with other person's attitude or actions in the work environment such as being late, delaying work or pretending to be ill to avoid doing work (Bernstein \& Nash 2006). Job satisfaction is a complex variable and is influenced by factors of the job situation including individual attitudes that cannot be changed (Judge, Weiss, Kammeyer-Mueller, \& Hulin, 2017). It is a multifaceted concept in which the acceptance of each individual is different from one another. Job satisfaction is often associated with motivation, but it is different from job motivation. Job satisfaction is more about attitude and inner nature while motivation can influence it.

There are two types of job satisfaction that are classified based on a global study of job satisfaction. First, the overall feeling that workers have about their job (for example, "overall I like my job") (Mueller \& Kim, 2008). Second, facet or aspecat satisfaction refers to specific job-related feelings such as pay, benefits, and quality of influence with other colleagues (for example, "overall, I love my job, but my work schedule is difficult to manage") (Mueller \& Kim, 2008). Therefore, based on the meanings and types that have been classified by previous studies, job satisfaction can be expressed in three dimensions: first, job satisfaction is related to the emotional response of the worker to the job situation. Second, job satisfaction can be measured by expecting job performance to be in line with job description and thirdly, job satisfaction can be determined by job demand (Jensen \& Luthans, 2006; Judge et al., 2017). There are many factors that can affect a person's job satisfaction. According to Buitendach \& De Witte, (2005) job satisfaction is a complex construct and is influenced by the working 
environment and different attitudes of individuals. These factors can be isolated by looking at extrinsic and intrinsic factors (Kanfer, Frese, \& Johnson, 2017). Extrinsic factors include salary, opportunity, co-workers, and supervision. Intrinsic factors include personality, education, capacity and ability, age and marital status. However, these two factors often cooccur in affecting job satisfaction (Kanfer et al., 2017). There are many recent studies that show that job satisfaction affects one's job performance. For example, Patrick Kampkötter, (2016); Platis, Reklitis, \& Zimeras, (2015) found that employee performance and job satisfaction were related to one another. A study by (Khan, Nawaz, Aleem, \& Wasim, (2012) found that job satisfaction leads to better performance amongst the employees. This is because the more workers feel positive about their work, the more productive their work will be. In addition, job satisfaction is also related to life satisfaction, self-confidence, physical and psychological health, customer satisfaction, attendance, employee productivity, employee performance and employee turnover (Gülnar, 2007; Shamailan, 2015). This indicates that employees who are satisfied with their job tend to cooperate, assist, emphatatic and perform well (Wilson \& Frimpong, 2004).

At the field of teaching, the main contributor towards teachers' satisfaction is process of engaging with positive influence on the students, intellectual challenges in teaching, and autonomy and freedom decision making (Nie, Chua, Yeung, Ryan, \& Chan, 2015; Zembylas \& Papanastasiou, 2004). This is because the profession requires a high degree of autonomy from most other professions as method of teaching needs to be constantly modified and adapted to meet the needs of different students (Collie et al., 2016). This is no exception to GDB. Although GDB is classified as a teacher with low competencies in teaching, the autonomy provided by SISC + while teaching can enhance their satisfaction. In addition, teachers' job satisfaction is also influenced by peers influence, administrators, and school achievement (Caprara, Barbaranelli, Steca, \& Malone, 2006; Dou, Devos, \& Valcke, 2017). It is also argued in the past studies that there are differences in the level of teachers' work satisfaction depending on the individual and type of school (Spear, Gould, and Lee, 2000). A teacher with high level of satisfaction will yield better teacher and they will be happy, obedient and committed (Ofoegbu, 2004). This is also shown by a study conducted by Skaalvik \& Skaalvik, (2017) who found that lack of job satisfaction can cause burnout among teachers and increase teachers' tendency to leave the teaching profession.

In the Malaysian context, a study on job satisfaction by Ghavifekr \& Pillai, (2016) on teachers in Penampang, Sabah found that the school organization climate has an impact on teachers' job satisfaction. This means that the relationship between administrators and teachers, the connectivity between teachers and colleagues, school achievement (teachers and students) and the influence on the community affect teachers' job satisfaction. In addition, a study conducted by Abdul, Tareq, \& Ling, (2015) found that psychological barriers affect teachers' job satisfaction. This finding shows that when teachers are given responsibilities that do not conflict with their values and beliefs, it will further enhance their job satisfaction and intrinsic motivation. Based on the examples of past research, it safe to conclude that job satisfaction is a very important factor in determining GDB job performance.

\section{Basic Psychological Need Influence on Motivation}

Basic Psychological Needs (BSPN) is essential as they provide a basis for predicting aspects of social context that will support intrinsic motivation and facilitate extrinsic motivation. These three basic psychological needs enable expectations and predictions to be made about one's behaviour in their social environment. In addition, the need for autonomy, competence and 
connectivity will not only increase the individual intrinsic motivation, but it also promotes the internalization of individual extrinsic motivation through integration of new rules and consequently affects their autonomous motivation (referring to intrinsic, integrated, identified motivation regulation). In the event that not all of these requirements are met, these motivational regulation will only be partially integrated and have a greater impact on controlled motivations such as external regulation and introjected regulation (Deci, Eghari, Patrick, \& Leone, 1994).

There have been numerous studies in various fields showing that these three basic psychological needs will enhance intrinsic motivation and facilitate internalization for extrinsic motivation. Consequently, it will reinforce attitude change, good performance, job satisfaction, positive work values and psychological adjustment (Gagné et al., 2008). In the field of education, there are also recent findings that show relation between the two elements such as the study conducted by Carson \& Chase, (2009; Taylor, Ntoumanis, \& Standage, (2008) examined the effects of basic psychological needs on self-motivation among Physical Education teachers. The results show that the more teachers feel their psychological needs are met, the higher their autonomous motivation to do their work.

In order to achieve need of autonomy, it will promote complete (Gagné \& Deci, 2005; Ryan \& Deci, 2000). The more autonomy needs are fulfilled, the higher the autonomous motivation will be (Deci \& Ryan, 1987) which includes intrinsic motivation. Several recent empirical studies have been showing the importance of autonomy in influencing intrinsic motivation, integrated regulation and identified rules such as a study conducted (Nie et al., 2015) on teachers in two government schools in China. They found that there is influence between autonomy and intrinsic motivation, integrated regulation and identified regulation amongst workers in organization. In addition, there have been other studies conducted on sports athletes (Gagne, Ryan, \& Bargmann Kelly, 2003), medical students (Kusurkar \& Croiset, 2015) and Japanese students learning English (Oga-Baldwin, Nakata, Parker, \& Ryan, 2017). These studies found that autonomy did influence intrinsic motivation, integrated regulation and identified regulation.

In addition to the effects of autonomy on intrinsic motivation and two extrinsic regulation (i.e. integrated and identified regulations), the internalization process also affects other elements of extrinsic motivation (i.e. introjected regulation and external regulation. A study conducted in China for instance found that there is an influence between autonomy and introjected regulation, external regulation and amotivation of workers (Nie et al., 2015).

For the needs of competency, relative internalization for extrinsic motivated acts is also existence function of competency. Individuals are better prepared to accept activities that are in line with their social group values when they feel they have the ability to perform them. As is the case with intentional actions, the SDT suggests that support for competencies is needed to assist internalization process (Vallerand, Pelletier, \& Blais, 1992). For example, children who are asked to perform a task or cognitively unprepared task as the aim to master the task will only partially internalize the said process. It is due to the effect of competency as their basic psychological needs..

Furthermore, the fulfilled competency provides opportunity for the individual to adapt to a complex and changing environment and thus influence their motivation. In a study conducted by Landry et al., (2017) on workers in Greece, they found that there is a positive correlation between competency with intrinsic motivation, integrated and identified regulation. They also recognize that these positive correlations eventually affect the performance of the employee.In addition, a study conducted by Stupnisky, BrckaLorenz, Yuhas, \& Guay, (2018) 
on lecturers from 1671 faculty at 19 universities found that there was a significant effect of competency with intrinsic motivation and set of regulations and thus impact their effective teaching. Moreover, there are studies that show the influence of competency and elements in other extrinsic motivations such as introjected and external regulation. For example, a study conducted by Agawa \& Takeuchi, 2016) on Japanese students found that by fulfilling the students competency needs it would have an impact on their extrinsic motivation (external regulation) in learning English.

In addition, changes in the work environment lead to greater satisfaction for these three basic psychological needs that will also encourage internalization, thereby affecting other autonomous motivations (Gagné \& Deci, 2005). For example, for the process of internalization to occur in the workplace, a person's relatedness needs must be met through interaction and socialization with other colleagues (Deci, Ryan, Vallerand, Pelletier, \& Ryan, 1991; Gagné \& Deci, 2005). In education, there are studies conducted to examine the influence of relatedness on the students' intrinsic motivation to study in college. For example, a study conducted by (Goldman, Goodboy, \& Weber, 2017), shows that there is an effect between student relatedness with student intrinsic motivation. This study also shows that the relatedness between students and teachers affects their intrinsic motivation to learn.

These findings indicate that social interactions are important in enhancing their intrinsic motivation to learn. Besides, there are also studies that show correlations between relatedness with other elements of extrinsic motivation. For instance, a study conducted on CrossFit participants (fitness training) found that relatedness affects the introjected regulation and external regulation of the participants involved in the fitness training (Babkes, Davies, \& Coleman, 2016). In addition, a study by Agawa \& Takeuchi, (2016) found that relatedness affects the amotivation of students learning English in Japan. It shows that the good interaction between students and teachers causes students to learn English even though they have no reason to learn it. Thus, it clearly shows that relatedness has an effect on the motivational elements within Self-Determination Theory.

However, relatedness alone is insufficient to cause internalization process to occur as it must be accompanied by competency. If only the needs of competency and relatedness are met, then only partial internalization process occurred. Moreover, the best that can be achieved is identified regulation (Ryan \& Deci, 2000). Nevertheless, these three basic psychological needs are equally important and necessary for optimal internalization process (Deci \& Ryan, 1987; Deci et al., 1991).

\section{Motivation Influence on Work Commitment and Satisfaction}

In the earlier discussion, it has been shown that work commitment and satisfaction are very important in determining the quality and performance of a teacher. It is also essential to note that this commitment and satisfaction can be influenced by a number of factors such previously described motivational elements which characterize each individual's behaviour based on the type of motivation. Previous studies have shown that there is a positive effect of motivation on workers' commitment and job satisfaction (Hasanah et al., 2016; Klusmann, Kunter, Trautwein, Lüdtke, \& Baumert, 2008; Lee, Lee, \& Hwang, 2015). In addition, there have also been studies that report negative effects of amotivation on work commitment and satisfaction (e.g. Tremblay et al., (2009).

The most frequently mentioned element of motivation that has affected on work commitment and satisfaction is intrinsic motivation as it stimulates behaviour, affects emotions and behaviours that arise after gaining autonomy and motivation (effect) (Cho \& 
Perry, 2012; Deci \& Ryan, 1985; Lemyre, Treasure, \& Roberts, 2006). In addition, intrinsic motivation also protects employees from stress as well as negative emotions (Gagné et al., 2010; Lemyre, Roberts, \& Stray-Gundersen, 2007; Xanthopoulou, Bakker, Demerouti, \& Schaufeli, 2007). According to a study conducted by Gagné et al. (2010), they found that intrinsic motivation has an effect on optimism, job satisfaction, work commitment (affective and normative), personal-psychological health and well-being. This is also similarly founded by a study by Breaugh, Ritz, \& Alfes, (2018) on public servants in Switzerland where they found that there is a positive relationship between intrinsic motivation and job satisfaction..

For extrinsic motivation, it involves accepting contingencies such as certain incentives between certain behaviours and benefits (Gagné \& Deci, 2005). Workers who are extrinsically motivated will avoid unwanted results or consequences. They will try to seek benefit for them. However, this will reduce their satisfaction because when it comes to their autonomy needs, they will feel pressured or harassed by external contingency (Gagné \& Deci, 2005). Therefore, extrinsic motivation is more negatively associated with work-related psychological levels and may result in burnout. This was also demonstrated by Gagné et al., (2010) who found that extrinsic motivation had a negative effect on affective commitment and had a positive effect on psychological stress. Furthermore, the controlled motivation (i.e. introjected regulation and external regulation) is considered to be unstable detrimental for performance as it depends on external sources (Deci \& Ryan, 2002). Furthermore, based on past studies it shows that employees who are motivated by controlled motivation will have less engagement and poor performance in their jobs (e.g. Fernet et al., 2012; Guay et al., 2010). As such, it will also affect one's commitment and work satisfaction as Fernet,( 2011) shows that external regulation, amotivation has a negative effect on work satisfaction and commitment.

There are also recent studies that prove the relevance of these motivational elements to teachers. A study conducted in Chinese teachers by Nie et al., (2015) found that autonomous motivation (intrinsic, integrated and identified regulations) had a positive effect on work satisfaction. Furthermore, the findings indicated that controlled motivation (introjected regulation and external regulation) had an effect on work stress. Although there are negative influences, the findings of this study clearly showed that there is a correlation between motivation and work commitment and satisfaction. Therefore, it presents the importance of motivation among teachers because if teachers are not motivated to commit to work, they will not be able to show good results despite possessing good knowledge and skills.

\section{Theoretical and Conceptual Framework}

The theoretical framework of this study on the theoretical discussion in the earlier section of this article. Figure 2 shows the theoretical framework of this study which visualize the basic psychological needs and motivational elements according to its divisions as stated by Deci \& Ryan, (2010). 


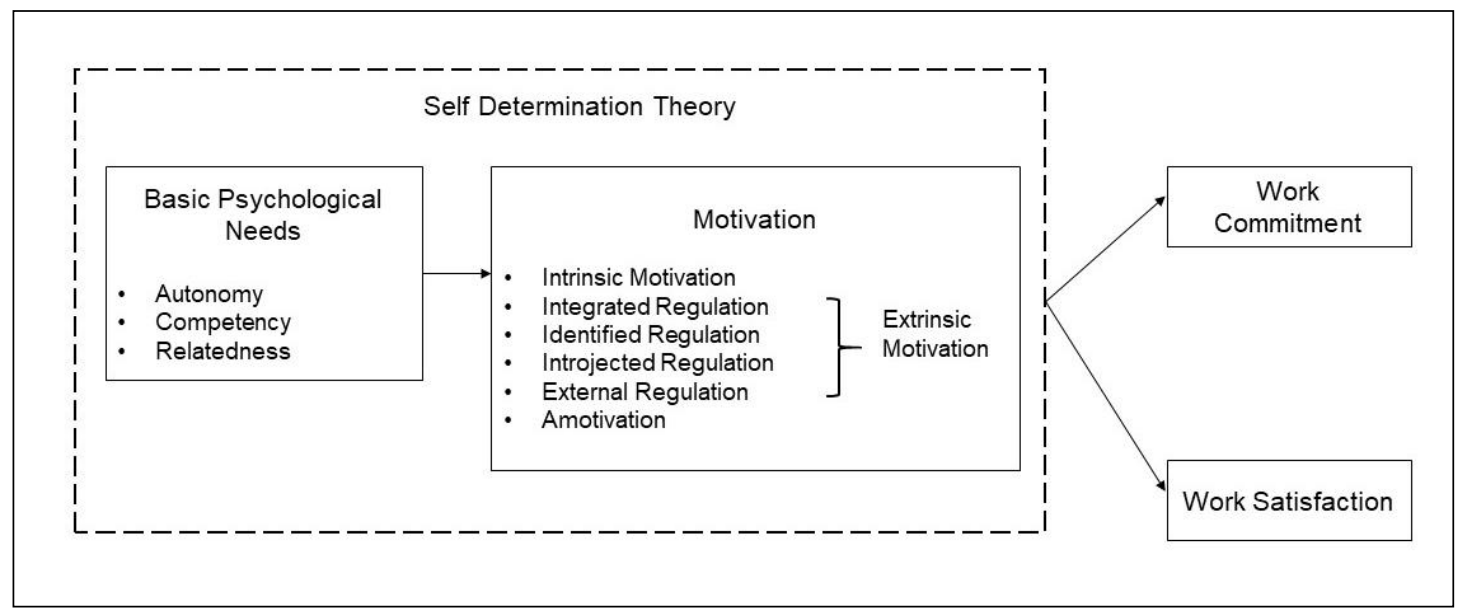

Figure 0: Research Theoretical Framework

The conceptual framework for this study is shown in Figure 3 where there are three elements of Basic Psychological Needs (BSPN) namely autonomy, competency and relatedness. The BSPN influence capacity will be tested against motivational elements comprises of intrinsic motivation, regulation within extrinsic motivation namely integrated regulation, identified regulation, introjected regulation and external regulation and also the last motivation element which is amotivation. All three elements of this BSPN need to be tested individually in relation to each motivation elements. Next, each motivation elements will be tested their influence capacity toward GDB's work commitment and satisfaction.

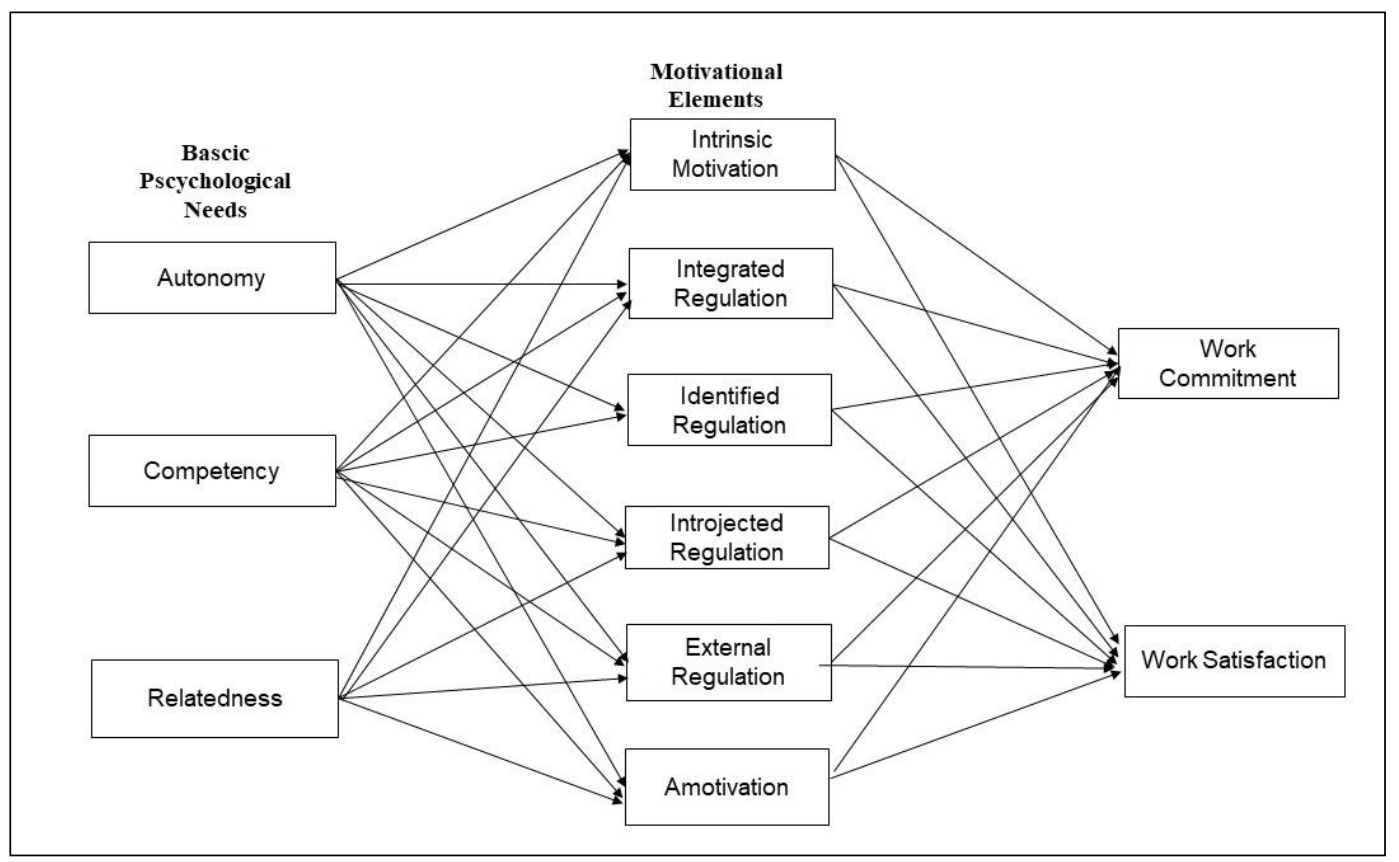

Figure 3: Research Conceptual Framework

\section{Conclusion and Way Forward}

In conclusion, this article has suggested that Basic Psychological Needs (BSPN) is the essential antecedent that has influence capacity in teachers' motivation. The concept of motivation is also being scrutinized by including intrinsic motivation, extrinsic motivation (which comprises 
of several regulations) and amotivation. These elements were argued to have an influence on guided teachers' work commitment and satisfaction. A thorough discussion of SelfDetermination Theory (SDT) has also been presented in this article and had allowed the formation of the theoretical framework for this study. A conceptual framework showing the relationship for each element was also shown at the end of this article.

The findings from this study are essential inputs in the psychological study. Furthermore, the findings are useful for determining the basic psychological needs amongst guided teachers. It provides an alternative insight from current psychological perspectives which focus more on extrinsic-intrinsic dichotomy. The elaborate discussion on extrinsic motivation spectrum provide an important guide for future study to measure motivation factors within educational sectors. The future study shall be benefited from the fundamental outline developed by this study.

Moreover, it is important to comprehensively discuss the construction of both theoretical and conceptual elements for this study as it will be the underlying foundation that describes the direction of future study. Consequently, the future study shall focus on instrument development and validation as well as constructing and testing hypotheses for each relationship found in this article. Henceforth, the influence capacity of both BSPN and motivation elements can be empirically determined.

\section{Corresponding Author}

Nor Aniza Ahmad

Faculty of Educational Studies, Universiti Putra Malaysia, 43400 UPM Serdang, Selangor, Malaysia

Email: nor_aniza@upm.edu.my

\section{References}

A Publication of The Education Trust. (1998). How well-qualified teachers can close the gap. The Education Trust, 3(2), 3-18. Retrieved from https://files.eric.ed.gov/fulltext/ED457260.pdf

Abdul, G. K. bin A., Tareq, Z. A., \& Ling, Y.-L. (2015). Psychological empowerment, job satisfaction and commitment among Malaysian secondary school teachers. Asian Journal of Educational Research, 3(3), 34-42. Retrieved from www.multidisciplinaryjournals.com

Agawa, T., \& Takeuchi, O. (2016). Validating self-determination theory in the Japanese EFL context: Relationship between innate needs and motivation. Asian EFL Journal, 18(1), 7-33.

Akram, M., Malik, M. I., Sarwar, M., Anwer, M., \& Ahmad, F. (2015). Relationship of teacher competence with professional commitment and job satisfaction at secondary level. International Journal of AYER, 4, 58-70.

Babkes, M., Davies, M. J., \& Coleman, L. (2016). The relationship between basic psychological need satisfaction. Journal of Sport Behavior, 39(3), 239-255. Retrieved from http://scholarlycommons. pacific.edu/cgi/viewcontent.cgi?article=1107\&context=copfacarticles

Bandura, A. (1978). Self-efficacy: Toward a unifying theory of behavioral change. Advances in Behaviour Research and Therapy. https://doi.org/10.1016/0146-6402(78)90002-4

Bandura, A. (1991). Social cognitive theory of self-regulation. Organizational Behavior and 
Human Decision Processes. https://doi.org/10.1016/0749-5978(91)90022-L

Banerjee, N., Stearns, E., Moller, S., \& Mickelson, R. A. (2017). Teacher job satisfaction and student achievement: The roles of teacher professional community and teacher collaboration in cchools. American Journal of Education, 123(2), 203-241. https://doi.org/10.1086/689932

Bassi, M., Meghir, C., \& Reynoso, A. (2019). Education quality and teaching practices (No. 22719). SSRN Electronic Journal. https://doi.org/10.2139/ssrn.3403030

Baumeister, R., \& Leary, M. (1995). The need to belong : Desire for interpersonal attachments as a fundamental human motivation. Psychoogical Bulletin, 117(3), 497529.

Bernstein, D., \& Peggy, N. W. (2006). Essentials of Psychology (4th ed.). Cengage Learning. Bhuian, S. N., \& Menguc, B. (2002). An extension and evaluation of job characteristics, organizational commitment and job satisfaction in an expatriate, guest worker, sales setting. Journal of Personal Selling and Sales Management, 22(1), 1-11. https://doi.org/10.1080/08853134.2002.10754288

Breaugh, J., Ritz, A., \& Alfes, K. (2018). Work motivation and public service motivation: disentangling varieties of motivation and job satisfaction. Public Management Review, 20(10), 1423-1443. https://doi.org/10.1080/14719037.2017.1400580

Broeck, A., Vansteenkiste, M., \& Witte, H. (2010). Capturing autonomy, competence, and relatedness at work: Construction and initial validation of the Work-related Basic Need Satisfaction scale. Of Occupational and \{...\}. Retrieved from http://onlinelibrary.wiley.com/doi/10.1348/096317909X481382/full

Buchanan, B. (1974). Building Organizational Commitment: The Socialization of Managers in Work Organizations. Administrative Science Quarterly, 533-546.

Buitendach, J., \& De Witte, H. (2005). Job insecurity, extrinsic and intrinsic job satisfaction and affective organisational commitment of maintenance workers in a parastatal. South African Journal of Business Management, 36(2), 27. Retrieved from http://content.ebscohost.com.library3.webster.edu/ContentServer.asp?T=P\&P=AN\&K= 17535040\&S=R\&D=aph\&EbscoContent=dGJyMNXb4kSeqLA4xNvgOLCmrOqeqK5Srqu4S 6+WxWXS\&ContentCustomer=dGJyMPGut1G1qLdKuePfgeyx44Dt6fIA\%5Cnhttp://librar y3.webster.edu/login?url=http://se

Caprara, G. V., Barbaranelli, C., Steca, P., \& Malone, P. S. (2006). Teachers' self-efficacy beliefs as determinants of job satisfaction and students' academic achievement: $A$ study at the school level. Journal of School Psychology, 44(6), 473-490. https://doi.org/10.1016/j.jsp.2006.09.001

Carson, R. L., \& Chase, M. A. (2009). An examination of physical education teacher motivation from a self-determination theoretical framework. Physical Education \& Sport Pedagogy, 14(4), 335-353. https://doi.org/10.1080/17408980802301866

Cho, Y. J., \& Perry, J. L. (2012). Intrinsic motivation and employee attitudes: Role of managerial trustworthiness, goal directedness, and extrinsic reward expectancy. Review of Public Personnel Administration, 32(4), 382-406. https://doi.org/10.1177/0734371X11421495

Cohen. (2003). Multiple Commitments in the Workplace : An Integrative Approach. Pschology Press (1st editio). New York: Taylor \& Francis Group. https://doi.org/10.1016/j.mcna.2011.08.008

Collie, R. J., Shapka, J. D., Perry, N. E., \& Martin, A. J. (2016). Teachers' psychological functioning in the workplace: Exploring the roles of contextual beliefs, need 
satisfaction, and personal characteristics. Journal of Educational Psychology, 108(6), 788-799. https://doi.org/10.1037/edu0000088

Crosswell, L. (2006). Understanding teacher commitment in time of change (Doctoral dissertation). Retrieved from http://eprints.qut.edu.au/16238/1/Leanne_Crosswell_Thesis.pdf

Csikszentmihalyi, M., \& Rathunde, K. (1992). The measurement of flow in everyday life: Toward a theory of emergent motivation. In Developmental perspectives on motivation (pp. 57-97). Lincoln, NE: US: University of Nebraska Press. https://doi.org/10.5962/bhl.title.7369

Darling-Hammond, L. (2000). Teacher quality and student achievement. Education Policy Analysis Archives, 8(1), 1. https://doi.org/10.14507/epaa.v8n1.2000

De Charms, R. (2013). Personal causation: The internal affective determinants of behavior. Personal Causation: The Internal Affective Determinants of Behavior. New York: Routledge. https://doi.org/10.4324/9781315825632

De Ketele, J.-M. (1996). L'évaluation des acquis scolaires: quoi? pourquoi? pour quoi? [The acquisition of school learning: what? why? and for what?]. Revue Tunisienne Des Sciences de l'éducation, (23), 17-26.

Deci, E. L., \& Ryan, R. M. (1985). Intrinsic Motivation and Self-Determination in Human Behavior. New York: Plenum.

Deci, E., Eghari, H., Patrick, B., \& Leone, D. (1994). Facilitating internalization: The selfdetermination theory perspective. Journal of Personality, 62(1), 119-142. https://doi.org/10.1037/0003-066X.55.1.68

Deci, E. L., \& Ryan, R. M. (1987). The support of autonomy and the control of behavior. Journal of Personality and Social Psychologyocial, 53(6), 1024-1037.

Deci, Edward, L., Connell, J. E., \& Ryan, R. M. (1989). Self-determination in a work organization. Journal of Applied Psychology, 74(4), 580-590. https://doi.org/10.1152/ajplung.00206.2012

Demirbolat, O., Ihtiyaro, N., \& Karaba, E. (2017). An investigation of the relationship between the affective, normative, and continuance commitment of teachers and levels of effectiveness. European Journal of Education Studies, 3(7), 38-56. https://doi.org/10.5281/zenodo.805996

Dinham, S., \& Scoot, C. (2000). Teacher Satisfaction, Motivation and Health: Phase One of the Teacher 2000 Project.

Dou, D., Devos, G., \& Valcke, M. (2017). The relationships between school autonomy gap, principal leadership, teachers' job satisfaction and organizational commitment. Educational Management Administration and Leadership, 45(6), 959-977. https://doi.org/10.1177/1741143216653975

Fernet, C. (2011). Development and validation of the work role motivation scale for school principals (WRMS-SP). Educational Administration Quarterly, 47(2), 307-331. https://doi.org/10.1177/0013161X10385108

Fernet, C., Austin, S., Trépanier, S. G., \& Dussault, M. (2013). How do job characteristics contribute to burnout? Exploring the distinct mediating roles of perceived autonomy, competence, and relatedness. European Journal of Work and Organizational Psychology, 22(2), 123-137. https://doi.org/10.1080/1359432X.2011.632161

Fernet, C., Stepanie, A., \& Vallerand, R. J. (2012). The effects of work motivation on employee exhaustion and commitment: An Extention of the JD-R Model. Work \& Stress, 26(3), 213-229. 
https://doi.org/http://dx.doi.org/10.1080/02678373.2012.713202 http://www.tandfonline.com

Gagne, M., Ryan, R. M., \& Bargmann Kelly. (2003). Autonomy support and need satisfaction in the motivation and well-Being of gymnasts. Journal of Applied Sport Psychology, 15, 372-390. https://doi.org/10.1080/10413200390238031

Gagné, M, \& Deci, E. L. (2005). Self-determination theory and work motivation. Journal of Organizational Behavior. Retrieved from http://onlinelibrary.wiley.com/doi/10.1002/job.322/full

Gagné, Marylène, Chemolli, E., Forest, J., \& Koestner, R. (2008). A temporal analysis of the relation between organisational commitment and work motivation. Psychologica Belgica, 48(2-3), 48-2. https://doi.org/10.5334/pb-48-2-3-219

Gagné, Marylène, Forest, J., Gilbert, M. H., Aubé, C., Morin, E., \& Malorni, A. (2010). The motivation at work scale: Validation evidence in two languages. Educational and Psychological Measurement, 70(4), 628-646. https://doi.org/10.1177/0013164409355698

Geldenhuys, M., Łaba, K., \& Venter, C. M. (2014). Meaningful work, work engagement and organisational commitment. SA Journal of Industrial Psychology. https://doi.org/10.4102/sajip.v40i1.1098

Ghavifekr, S., \& Pillai, N. S. (2016). The relationship between school's organizational climate and teacher's job satisfaction: Malaysian experience. Asia Pacific Education Review, 17(1), 87-106. https://doi.org/10.1007/s12564-015-9411-8

Glasser, W. (1986). Control theory in the classroom. Control theory in the classroom. New York, NY, US: Perennial Library/Harper \& Row Publishers.

Goldman, Z. W., Goodboy, A. K., \& Weber, K. (2017). College students' psychological needs and intrinsic motivation to learn: An examination of self-determination theory. Communication Quarterly, 65(2), 167-191. https://doi.org/10.1080/01463373.2016.1215338

Graham, K. C. (1996). Running Ahead: Enhancing Teacher Commitment. Journal of Physical Education Reaction and Dance, 67, 45-47.

Gülnar B. (2007). "The Relationship Between Communication Satisfaction And Job Satisfaction: A Survey Among Selcuk Unıversity Research Assistants." In E. Yüksel (Ed.), Fifth International Symposium Communication in The Millenium, (pp. 190-205). Bloomington-United States of America: Indiana University School of Journalism.

Hackman, J. R., \& Oldham, G. R. (1976). Motivation through the design of work: test of a theory. Organizational Behavior and Human Performance. https://doi.org/10.1016/0030-5073(76)90016-7

Hasanah, N., Isa, M., Romle, A. R., Udin, M. M., Zahirah, S., Zahid, M., ... Mohamad, H. (2016). Relationship Between Motivation and Commitment on Job Performance among Employees in Higher Education from Students ' Perspective. World Applied Sciences Journal, 34(3), 400-407. https://doi.org/10.5829/idosi.wasj.2016.34.3.15673

Hatlevik, I. K. R. (2017). The impact of prospective teachers' perceived competence on subsequent perceptions as schoolteachers. Teachers and Teaching: Theory and Practice, 23(7), 810-828. https://doi.org/10.1080/13540602.2017.1322056

Hill, P. W., \& Crévola, C. A. (1999). Early Years Literacy Program, (October), 1-14. Hollins, E. R. (2015). Culture in School Learning: Revealing the Deep Meaning: Third Edition. Culture in School Learning: Revealing the Deep Meaning: Third Edition. https://doi.org/10.4324/9781315813615 
Holzberger, D., Philipp, A., \& Kunter, M. (2014). Predicting teachers' instructional behaviors: The interplay between self-efficacy and intrinsic needs. Contemporary Educational Psychology. Retrieved from http://www.sciencedirect.com/science/article/pii/S0361476X14000095

Howard, J., Gagné, M., Morin, A. J. S., \& Van den Broeck, A. (2016). Motivation Profiles at Work: A Self-Determination Theory Approach. Journal of Vocational Behavior, 95-96, 74-89. https://doi.org/10.1016/j.jvb.2016.07.004

Huber, M. (1999). Co-ordination within schools, commitment of teachers and students and student achievement. International Journal of Phytoremediation, 21(1), 139-156. https://doi.org/10.1076/edre.5.2.139.6939

Izab, F. (2015). SISC+ bantu lahir guru berkemahiran tinggi, murid kreatif. Utusan Melayu. Retrieved from http://www.utusan.com.my/berita/nasional/sisc-bantu-lahir-guruberkemahiran-tinggi-murid-kreatif-1.104986

Jang, H., Reeve, J., \& Deci, E. L. (2010). Engaging students in learning activities: It is not autonomy support or structure but autonomy support and structure. Journal of Educational Psychology, 102(3), 588-600. https://doi.org/10.1037/a0019682

Janssen, O. (2001). Fairness perceptions as a moderator in the curvilinear relationships between job demands, and job performance and job satisfaction. Academy of Management Journal. https://doi.org/10.2307/3069447

Jensen, S. M., \& Luthans, F. (2006). Entrepreneurs as authentic leaders: Impact on employees' attitudes. Leadership and Organization Development Journal, 27(8), 646666. https://doi.org/10.1108/01437730610709273

Judge, T. A., Weiss, H. M., Kammeyer-Mueller, J. D., \& Hulin, C. L. (2017). Journal of Applied Psychology of Continuity and of Change A Century of Continuity and of Change. Journal of Applied Psychology. https://doi.org/10.1037/apl0000181

Kaliski, B. S. (2007). Encyclopedia of Business and Finance (2nd Editio). Thompson Gale, Detroit.

Kanfer, R., Frese, M., \& Johnson, R. E. (2017). Motivation related to work: A century of progress. Journal of Applied Psychology. https://doi.org/10.1037/apl0000133

Karasek, R. A. (1979). Job demands, job decision latitude, and mental strain: Implications for job redesign. Administrative Science Quarterly, 24(2), 285-308. https://doi.org/10.2307/2392498

Kementerian Pendidikan Malaysia. (2013a). Panduan Program Transformasi Daerah untuk SIPartner+ dan SISC+. Putrajaya: Bahagian Pengurusan Sekolah Harian.

Kementerian Pendidikan Malaysia. (2013b). Pelan Pembangunan Pendidikan Malaysia 20132025. (KPM, Ed.), Malaysia Education Blueprint. KPM. Retrieved from https://www.moe.gov.my/images/dasar-kpm/PPP/articlefile_file_003107.pdf

Kementerian Pendidikan Malaysia. (2018). Laporan Pelaksanaan Pementoran Pakar Pembimbing Peningkatan Sekolah.

Khan, A. H., Nawaz, M. M., Aleem, M., \& Wasim, H. (2012). Relationship between job satisfaction, job performance, attitude towards work, and organizational commitment. Entrepreneurship and Innovation Management Journal, 2(2), 135-144. https://doi.org/10.5897/AJBM11.2222

Klusmann, U., Kunter, M., Trautwein, U., Lüdtke, O., \& Baumert, J. (2008). Engagement and emotional exhaustion in teachers: Does the school context make a difference? Applied Psychology, 57(SUPPL. 1), 127-151. https://doi.org/10.1111/j.1464-0597.2008.00358.x

Kosnik, C., Beck, C., \& Goodwin, L. A. (2016). Reform Efforts in Teacher Education. In 
International Handbook of Teacher Education: Volume 1 (pp. 267-308). Springer Singapore. https://doi.org/10.1007/978-981-10-0366-0_7

Kusurkar, R. A., \& Croiset, G. (2015). Autonomy support for autonomous motivation in medical education. Medical Education Online, 20(1). https://doi.org/10.3402/meo.v20.27951

Kyriacou, C. (2011). Teacher stress: From prevalence to resilience. In Handbook of stress in the occupations. (pp. 161-173). Northampton, MA, US: Edward Elgar Publishing.

Landry, A. T., Gagné, M., Forest, J., Guerrero, S., Séguin, M., \& Papachristopoulos, K. (2017). The relation between financial incentives, motivation, and performance: An integrative SDT-based investigation. Journal of Personnel Psychology, 16(2), 61-76. https://doi.org/10.1027/1866-5888/a000182

Langan, E., Hodge, K., McGowan, S., Carney, S., Saunders, V., \& Lonsdale, C. (2016). The influence of controlled motivation alongside autonomous motivation: Maladaptive, buffering, or additive effects? International Journal of Sport and Exercise Psychology, 14(1), 57-71. https://doi.org/10.1080/1612197X.2015.1016084

Lee, Y., Lee, J., \& Hwang, Y. (2015). Relating motivation to information and communication technology acceptance: Self-determination theory perspective. Computers in Human Behavior, 51(PA), 418-428. https://doi.org/10.1016/j.chb.2015.05.021

Lemyre, P.-N., Treasure, D. C., \& Roberts, G. C. (2006). Influence of variability in motivation and affect on elite athlete burnout susceptibility. Journal of Sport and Exercise Psychology, 28(1), 32-48.

Lemyre, P. N., Roberts, G. C., \& Stray-Gundersen, J. (2007). Motivation, overtraining, and burnout: Can self-determined motivation predict overtraining and burnout in elite athletes? European Journal of Sport Science, 7(2), 115-126. https://doi.org/10.1080/17461390701302607

Leng, E. Y. (2015). Appreciative inquiry as theory and practices in coaching mathematics teachers. In Conference: 4th Regional Conference on Educational Leadership and Management (RCELAM). Retrieved from https://www.researchgate.net/profile/Eow_Leng/publication/308929878_Appreciative _Inquiry_as_Theory_and_Practices_in_Coaching_Mathematics_Teachers/links/57f841 7d08ae280dd0bcce52.pdf

Louis, K. S. (1998). Effects of teacher quality of work life in secondary schools on commitment and sense of efficacy. School Effectiveness and School Improvement, 9(1), 1-27. https://doi.org/10.1080/0924345980090101

Marthis, R. I., \& Jackson, J. (2000). Human Resources Management. Academy of Management Review (Vol. 7). New Jersey: Prentice Hall.

McDermott, K., Laschinger, H. K. S., \& Shamian, J. (1996). Work empowerment and organizational commitment. Nursing Management, 27(5), 44-47. https://doi.org/10.1080/00006247-199605000-00010

McNeese-Smith, D. (1996). Increasing employee productivity, job satisfaction, and organizational commitment. Hospital and Health Services Administration, 41(2), 160175. Retrieved from https://search.proquest.com/openview/8b5a6229d236bc77d80be6341be15739/1?pqorigsite $=$ gscholar $\& \mathrm{cbl}=7080$

Miller, L. J. (2018). LEADER - EMPLOYEE RELATIONSHIP AS AN ANTECEDENT TO EMPLOYEE COMMITMENT MEDIATING INNOVATIVE WORK BEHAVIOR by. A Dissertation Presented in Partial Fulfillment of the Requirements for the Degree Doctor of Business 
Administration Capella University December 2018.

Mittal, M., \& Bhakar, S. S. (2018). Examining the impact of role overload on job stress, job satisfaction and job performance-A study among married working women in banking sector. International Journal of Management Studies, $V(2(7)), 01$.

https://doi.org/10.18843/ijms/v5i2(7)/01

Mohamad, R., Kasim, A. L., Zakaria, S., \& Nasir, F. M. (2017). Komitmen guru dan kepuasan kerja guru di sekolah menengah harian berprestasi tinggi dan berprestasi rendah di daerah Kota Bharu, Kelantan. Proceedings of the ICECRS, 1(1).

https://doi.org/10.21070/picecrs.v1i1.603

Morgeson, F. P., \& Humphrey, S. E. (2006). The Work Design Questionnaire (WDQ):

Developing and validating a comprehensive measure for assessing job design and the nature of work. Journal of Applied Psychology, 91(6), 1321-1339.

https://doi.org/10.1037/0021-9010.91.6.1321

Morrow. (1993). The Theory and Measurement of work Commitment (Vol 15th). Emerald Group Publishing Limited. Retrieved from https://www.bookdepository.com/TheoryMeasurement-Work-Commitment-Paula-C-Morrow/9781559385725

Mueller, C. W., \& Kim, S.-W. (2008). The Contented Female Worker: Still a Paradox? In Karen A. HegtvedtJody Clay-Warner (ed.) Justice (Advances in Group Processes (Vol. 25, pp. 117-149). Emerald Group Publishing Limited. https://doi.org/doi.org/10.1016/S08826145(08)25006-X

Munyaka, S. A., Boshoff, A. B., Pietersen, J., \& Snelgar, R. (2017). The relationships between authentic leadership, psychological capital, psychological climate, team commitment and intention to quit. SA Journal of Industrial Psychology, 43(0), 1-11. https://doi.org/10.4102/sajip.v43i0.1430

Nie, Y., Chua, B. L., Yeung, A. S., Ryan, R. M., \& Chan, W. Y. (2015). The importance of autonomy support and the mediating role of work motivation for well-being: Testing self-determination theory in a Chinese work organisation. International Journal of Psychology, 50(4), 245-255. https://doi.org/10.1002/ijop.12110

O'Neil, L., \& Hodge, K. (2019). Commitment in Sport: The Role of Coaching Style and Autonomous versus Controlled Motivation. Journal of Applied Sport Psychology, 0(0), 1-11. https://doi.org/10.1080/10413200.2019.1581302

Ofoegbu, F. I. (2004). Teacher motivation: A Factor for classroom effectiveness and school improvement in Nigeria. College Student Journal, 38(1), 81-89. Retrieved from http://search.proquest.com/docview/236508376?accountid=10673\%5Cnhttp://openur I.ac.uk/athens:_edu?url_ver=Z39.88-

2004\&rft_val_fmt=info:ofi/fmt:kev:mtx:journal\&genre=article\&sid=ProQ:ProQ\%3Aedu cation\&atitle=TEACHER+MOTIVATION\%3A+A+FACTOR+FOR+CLASSROOM+EFFEC

Oga-Baldwin, W. L. Q., Nakata, Y., Parker, P., \& Ryan, R. M. (2017). Motivating young language learners: A longitudinal model of self-determined motivation in elementary school foreign language classes. Contemporary Educational Psychology, 49, 140-150. https://doi.org/10.1016/j.cedpsych.2017.01.010

Patrick Kampkötter. (2016). Performance appraisals and job satisfaction. International Journal of Human Resource Management, 28(5), 750-774. https://doi.org/10.1080/09585192.2015.1109538

Platis, C., Reklitis, P., \& Zimeras, S. (2015). Relation between job satisfaction and job performance in healthcare services. Procedia-Social and Behavioral Sciences, 175, 480-487. https://doi.org/10.1016/j.sbspro.2015.01.1226 
Said, R., Brahim, M., \& Sabil, M. A. (2016). Bimbingan dan pementoran berfokus oleh SISC+ BM: Impak terhadap kualiti pengajaran guru Bahasa Melayu di sekolah-sekolah menengah daerah Samarahan, Sarawak (Focused Coaching and Mentoring by Sisc + Bm: Impact on Teaching Quality of the Malay Language Teac. Jurnal Pendidikan Malaysia, 41(2), 131-139. https://doi.org/10.17576/JPEN-2016-41.2-\%x

Reyes, P. (1992). Preliminary Models of Teacher Organizational Commitment: Implications for Restructuring the Workplace. Retrieved from https://files.eric.ed.gov/fulltext/ED349680.pdf

Robert W. W. (1959). Motivation Reconsidered: The Concept of Competence. Psychological Review, 66.

Ryan, R. M. (1995). Psychological needs and the facilitation of integrative processes. Journal of Personality, 63(3), 397-427. https://doi.org/10.1111/j.1467-6494.1995.tb00501.x

Ryan, R. M., \& Deci, E. L. (2000). Self-determination theory and the facilitation of intrinsic motivation, social development, and well-being. American Psychologist. Retrieved from http://psycnet.apa.org/journals/amp/55/1/68/

Ryan, R. M., Sheldon, K. M., Kasser, T., \& Deci, E. L. (1996). All goals are not created equal: An organismic perspective on the nature of goals and their regulation. In Psychology of Action: Linking Cognition and Motivation to Behavior. https://doi.org/papers://7EAF3440-77F6-4B89-B12D-846E31E57E4A/Paper/p3085

Saha, R. (2016). Factors influencing Organizational Commitment - Research and Lessons. Management Research and Practice, 8(3), 36-48.

Sanders, W. L., \& Horn, S. P. (1998). Research findings from the Tennessee Value-Added Assessment System (TVAAS) database: Implications for educational evaluation and research. Journal of Personnel Evaluation in Education, 12(3), 247-256. https://doi.org/10.1023/A:1008067210518

Seligman, M. E. P. (1975). Helplessness: On depression, development, and death. New York, NY, US: W H Freeman/Times Books/ Henry Holt \& Co. https://doi.org/10.5962/bhl.title.7369

Shafiq, M., \& Rana, A. R. (2016). Relationship of emotional intelligence to organizational commitment of college teachers in Pakistan. Egitim Arastirmalari - Eurasian Journal of Educational Research, (62), 1-14. https://doi.org/10.14689/EJER.2016.62.1

Shamailan, A. W. (2015). The relationship between job satisfaction, job performance and employee engagement: An explorative study. Issues in Business Management and Economics, 4(1), 1-8.

Siraj, S., \& Ibrahim, M. S. (2012). Standard Kompetensi Guru Malaysia. Retrieved from http://repository.um.edu.my/25208/1/STANDARD KOMPETENSI GURU MALAYSIA Saedah Siraj \%26 Mohammed Sani Ibrahim.pdf

Skaalvik, E. M., \& Skaalvik, S. (2017). Still motivated to teach? A study of school context variables, stress and job satisfaction among teachers in senior high school. Social Psychology of Education, 20(1), 15-37. https://doi.org/10.1007/s11218-016-9363-9

Skinner, E. A., \& Edge, K. (2002). Self Determination, Coping, and Development. In Handbook of self-determination research.

Spear, M., Gould, K., and Lee, B. (2000). Who Would be a Teacher?A Review of Factors Motivating and Demotivating Prospective and Practising Teachers. NFER, Slough.

Stupnisky, R. H., BrckaLorenz, A., Yuhas, B., \& Guay, F. (2018). Faculty members' motivation for teaching and best practices: Testing a model based on self-determination theory across institution types. Contemporary Educational Psychology, 53, 15-26. 
https://doi.org/10.1016/j.cedpsych.2018.01.004

Taylor, I. M., Ntoumanis, N., \& Standage, M. (2008). A self-determination theory approach to understanding the antecedents of teachers' motivational strategies in physical education. Journal of Sport and Exercise Psychology, 30(1), 75-94. https://doi.org/10.1123/jsep.30.1.75

Tremblay, M. A., Blanchard, C. M., Taylor, S., Pelletier, L. G., \& Villeneuve, M. (2009). Work Extrinsic and Intrinsic Motivation scale: its value for organizational psychology research. Canadian Journal of Behavioural Science, 41(4), 213-226. https://doi.org/10.1037/a0015167

Vallerand, R., Pelletier, L., \& Blais, M. (1992). The Academic Motivation Scale: A measure of intrinsic, extrinsic, and amotivation in education. Educational And.

Vansteenkiste, M., Lens, W., \& Deci, E. L. (2006). Intrinsic versus extrinsic goal contents in self-determination theory: Another look at the quality of academic motivation. Educational Psychologist, 41(1), 19-31. https://doi.org/10.1207/s15326985ep4101_4

Vroom, V. (1964). Expectancy theory. Work and Motivation. https://doi.org/10.4135/9781849208628

Wahyuddin, W. (2017). Headmaster leadership and teacher competence in increasing student achievement in school. International Education Studies, 10(3), 215. https://doi.org/10.5539/ies.v10n3p215

Wilson, A., \& Frimpong, J. (2004). A reconceptualisation of the satisfaction-service performance thesis. Journal of Services Marketing, 18(6), 471-481. https://doi.org/10.1108/08876040410557258

Xanthopoulou, D., Bakker, A. B., Demerouti, E., \& Schaufeli, W. B. (2007). The role of personal resources in the job demands-resources model. International Journal of Stress Management, 14(2), 121-141. https://doi.org/10.1037/1072-5245.14.2.121

Zembylas, M., \& Papanastasiou, E. (2004). Job satisfaction among school teachers in Cyprus. Journal of Educational Administration, 42(3), 357-374. https://doi.org/10.1108/09578230410534676 